Article Type: Research Paper

\title{
Willingness to Pay Analysis of First Fuel in Yogyakarta
}

\author{
Masniya Khairunnisa ${ }^{1} *$ and Lilies Setiartiti ${ }^{2}$
}

\begin{abstract}
This study aims to measure the value of willingness to pay and analyze the factors that affect consumer willingness to pay toward Pertamax fuel. This study's dependent variable is income, number of owned vehicles, the frequency of vehicle use, and product literacy. In this study sample of 100 Pertamax fuel users in Yogyakarta were selected using the Purposive Sampling method. This study using multiple linear regression or Ordinary Least Square (OLS). The results show that the value of consumer willingness to pay toward Pertamax fuel is $\mathrm{Rp}$. 10,545 . The factors that influence willingness to pay are income, frequency of vehicle use, and product literacy. These three variables are positive and have a significant influence on consumer willingness to pay toward Pertamaxfuel. While the variable number of the owned vehicle.

Keywords: Willingness to Pay; Income; Number of Owned Vehicles; The Frequency of Vehicle use and Product Literacy; Pertamax Fuel
\end{abstract}

DOI: $10.18196 /$ jerss.v4i2.10100

\section{CITATION:}

Khairunnisa, M., \& Setiartitie, L. (2020). Willingness to pay analysis of first fuel in Yogyakarta. Journal of Economics Research and Social Sciences, 4(2), 140-148.

\section{Introduction}

Oil Fuel (BBM) is essential for humans to support daily life and has an essential role in economic activity, both for consumption, production, and distribution needs. Before becoming a fuel, the main content of BBM came from the fossil of living things, both animals and plants, which had been buried hundreds of millions of years under the earth's surface, called petroleum.

In Indonesia, the demand for fuel is increasing along with the development of various domestic sectors, for example, in the industrial, household, and transportation sectors. Therefore, BBM can be said as a basic need that plays a critical role in society's daily life, both from the upper class and the lower class. This condition can be seen from how BBM dramatically affects the price of essential commodities and inflation. Currently, the most widely distributed use of BBM is to support the transportation sector's needs, where demand is increasing. It is estimated that this occurs because the number of motorized vehicles increases from year to year.

Through Pertamina, the Indonesian government has provided two alternative fuel options that the public can use, namely subsidized and non-subsidized fuel. However, because subsidized fuel has a lower price, people prefer to use it to save money. In terms of quality, non-subsidized fuel has better quality than subsidized fuel. 


\section{Khairunnisa \& Setiartitie \\ Willingness to Pay Analysis of First Fuel in Yogyakarta}

In terms of Research Octane number (RON), Pertamax BBM has a higher RON 92 than RON from Pertalite, namely RON 90 and Premium with RON 88. Where the higher the RON, the better for the vehicle. As quoted in (Rankovic, Bourhis, Loos, \& Dauphin, 2015) that the octane quality of the fuel is very important for the vehicle to avoid knocking. Therefore, the higher the RON, the better for combustion in the vehicle. Based on this, it can be seen that the quality of Pertamax is better than subsidized fuel. For example, Premium types and Pertamina strongly recommend its use, especially for vehicle output from 2000 and above. In the current era of globalization, the use of Pertamax fuel is very suitable because it is classified as an environmentally friendly fuel that can reduce environmental pollution from the exhaust gases of vehicles using subsidized Premium types of fuel. However, in recent years, at the end of 2017, the world was shocked by the world oil price, which reached 70 US $\$$ / barrel for the first time in the last three years. It is predicted that the leading cause of the increase in world oil prices is due to the policy of production cuts that have been agreed upon by the OPEC (Organization of the Petroleum Exporting Countries) member countries at the end of 2016. The increase in world oil prices continues until 2018, which causes the price in Indonesia has also risen because the primary raw material for BBM is crude oil. From the increase in fuel prices.

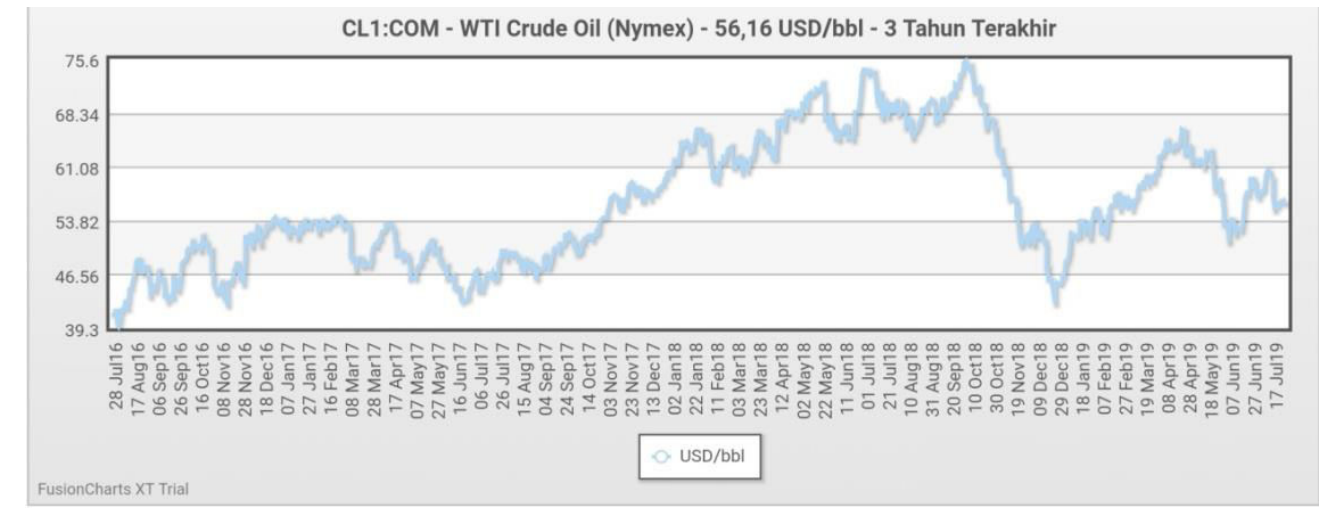

Figure 1 World Oil Prices

Source: https://hargaminyak.net/trend-grafik/WTI-Crude-Oil-Nymex/

Figure 1 shows that the movement of world oil prices starts from the end of 2017 and lasting until 2018. However, in early 2019 the world oil price stabilized so that in February 2019, Pertamina took a policy to adjust prices to compile a downward trend in crude oil prices. The world and the strengthening of the rupiah against the US dollar. Apart from that, Pertamina also pays attention to people's purchasing power.

In Yogyakarta itself, after the price adjustment occurred, consumption of non-subsidized fuel was already high, and it shifted subsidized fuels such as Premium and Solar. The increase in non-subsidized fuel consumption in Yogyakarta Special Region is due to the increasing public awareness to use quality and environmentally friendly fuel. As of October 28, 2018, alone, according to data from MOR IV Central Java DIY, the highest absorption rate in the Yogyakarta region was Pertamax at $16.6 \%$, which is the second largest after Pertalite at $68 \%$, shifting Premium, whose market is only $15 \%$ followed by 


\section{Khairunnisa \& Setiartitie \\ Willingness to Pay Analysis of First Fuel in Yogyakarta}

other types of fuel. As Teuku Johan Miftah said as the Branch Manager of Pertamina MOR IV DIY and Surakarta, said:

"Judging from the trend of non-subsidized fuel sales itself, it is increasing and well known to the public in Yogyakarta, such as Pertalite, Pertamax, and others. This non-subsidized fuel product variant has proven to be beneficial for vehicles so that many people have switched and chose to use it at this time".

Given that DI Yogyakarta itself is a city of students, with an adequate level of understanding of a product, Pertamax fuel price rising to some degree some time ago. As a consumer who uses it and knows how the advantages are obtained when using Pertamax BBM, it will affect the purchase of fuel. For this reason, it is necessary to do an economic valuation, which is useful to see how much value is given by consumers for quality fuels such as Pertamax fuel. The economic valuation is carried out using the willingness to pay through the Contingent Valuation Method (CVM) approach. By using this approach, the correct value for the item will be obtained.

\section{Literature Review}

This research refers to several studies using the same method, such as research conducted by (Daud \& Aidar, 2017), which aims to analyze the desire of the people of Banda Aceh City to pay for the availability of the Solar Home System (SHS) and the factors that influence it. This study shows that the variables that influence people's willingness to pay positively and significantly are income, knowledge of the solar home system, and the tariff group strata. In contrast, the education variable has a positive but insignificant effect.

Furthermore, the research conducted by (Lestari \& Aliasuddin, 2016) aims to determine the community's willingness to pay (WTP) for natural gas networks in Lhokseumawe City using the primary data sample size of 100 households conducted by purposive sampling. This study's regression model shows that income and education have a positive and significant effect on natural gas WTP in this area. The average economic value is IDR $2,614,008$. Based on the results, it is recommended to limit the gas network in Lhokseumawe and other areas of Aceh.

In addition to research using the same method, previously, several studies examined the factors that influence consumers to buy Pertamax fuel. As research conducted by (Fauzan, 2018) states, revenue and vehicle type significantly affect Pertamax fuel demand in Purwokerto. Other factors such as Pertamax price, Pertalite price, and vehicle year do not affect Pertamax fuel. This study shows that the people in Purwokerto tend to keep quality at any government's price level. Furthermore, research was conducted by (Rahman, 2015). This study indicates that the quality of Pertamax fuel affects consumer decisions to buy Pertamax fuel. 


\section{Research Method}

\section{Types and Sources of Data}

The sampling technique is a process of determining the number of samples that are part of the population consisting of some members selected from the population, which aims to study the sample subject's character so that researchers can draw conclusions that will be generalized to the population.

\section{Analysis Tools}

To analyze the factors that influence willingness to pay Pertamax fuel consumption is done using multiple linear regression analysis or Ordinary Least Square (OLS) using SPSS 21. The regression analysis is used to determine whether there is an effect between variables by studying changes in the value of the dependent variable caused by changes in the value of the independent variable that can affect these variables. Moreover, regression analysis that will be used in this study is to use the multiple linear regression analysis (OLS) approaches. The linear regression equation used in this analysis is:

$$
Y=a+++++\epsilon b_{1} X_{1} b_{2} X_{2} b_{3} X_{3} b_{4} X_{4}
$$

Where:

$\mathrm{Y}=$ Willingness to Pay

$a=$ constant numbers

$b_{1}=$ income correlation coefficient

$X_{1}=$ income

$b_{2}=$ the correlation coefficient of the number of vehicles owned

$X_{2}=$ number of vehicles owned

$b_{3}=$ vehicle's use frequency correlation coefficient

$X_{3}=$ frequency of vehicle use

$b_{4}=$ product literacy correlation coefficient

$X_{4}=$ product literacy

$\epsilon \quad=$ Error Term

\section{Result and Discussion}

\section{WTP and Consumer Surplus}

Based on the results of a survey of 100 respondents, the total willingness to pay (WTP) for Pertamax BBM in Yogyakarta was IDR 1,054,500.00 with an average WTP per person of IDR 10,545.00. The amount of WTP is influenced by income, the number of vehicles owned, vehicle use frequency, and product literacy. From the total WTP, it can be seen that the total consumer surplus of 100 respondents. Consumer surplus is the difference between the amount paid by consumers for goods and services and the WTP. The 
current Pertamax fuel price after the price adjustment is IDR 9,850.00. The total consumer surplus can be determined by reducing the total WTP with the Pertamax fuel price distributed by 100 respondents. Based on the total consumer surplus of 100 people, it is IDR 1,054,500.00 - $(100 \times$ IDR 9,850.00) $=$ IDR 65,500.

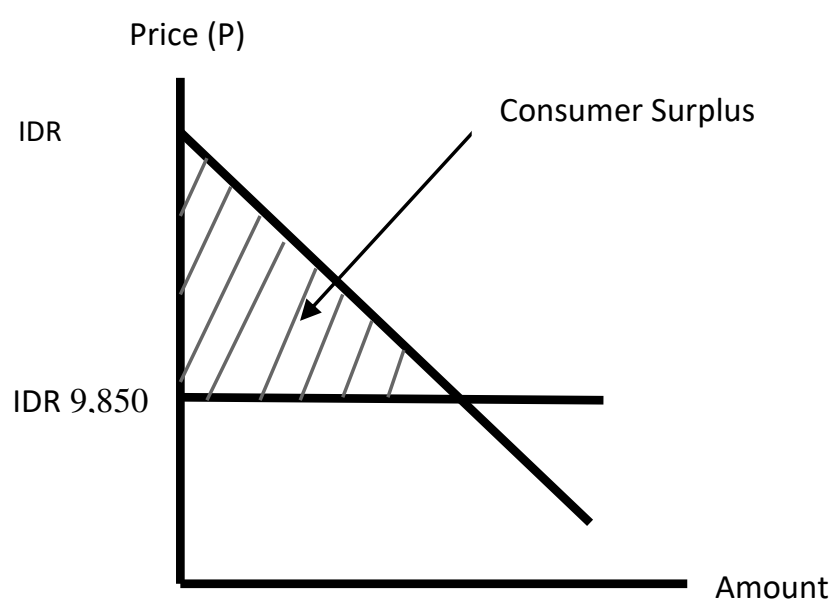

Figure 2 Consumer Surplus Curve

Based on the Figure 2, it can be seen that out of 100 respondents, they are willing to pay more to get Pertamax BBM. This finding can be used as input for the Government and PT Pertamina (Persero) in terms of price change policies from Pertamax with a maximum limit equal to the average consumer surplus. However, with this increase, it must be balanced with an even better-quality improvement. In the future, it is hoped that more Yogyakarta people will switch from using subsidized fuel to using non-subsidized fuel such as Pertamax.

\section{Regression Results and Discussion}

In this study, the t-test was conducted to determine whether the variable income, number of vehicles owned, frequency of vehicle use, and product literacy partially (respectively) affect the willingness to pay variable. The following are the results of the Table 1.

Table 1 T-Test Result (Partial)

\begin{tabular}{|c|c|c|c|c|c|}
\hline \multirow[t]{2}{*}{ Model } & \multicolumn{2}{|c|}{ Unstandardized Coefficients } & \multirow{2}{*}{$\begin{array}{c}\text { Standardized } \\
\text { Coefficients } \\
\text { Beta }\end{array}$} & \multirow[t]{2}{*}{$\mathrm{T}$} & \multirow[t]{2}{*}{ Sig } \\
\hline & $\mathrm{B}$ & Std.Error & & & \\
\hline (Constant) & 7753,506 & 309,834 & & 25,025 & .000 \\
\hline Income & 66,085 & 14,685 & .349 & 4,500 & .000 \\
\hline $\begin{array}{l}\text { Number of } \\
\text { vehicles }\end{array}$ & 22,994 & 19,373 & .086 & 1,187 & .238 \\
\hline Frequency & 47,304 & 12,058 & .305 & 3,923 & .000 \\
\hline $\begin{array}{l}\text { Product } \\
\text { literacy }\end{array}$ & 57,743 & 14,229 & .309 & 4,058 & .000 \\
\hline
\end{tabular}

Source: Primary data processed 


$$
Y=0,349 \times 1+0,086 \times 2+0,305 X 3+0,309 \times 4+\epsilon
$$

\section{The Effect of Product Literacy on Willingness to Pay}

This study indicates that the product literacy variable has a positive correlation coefficient and significantly affects the consumer's willingness to pay for Pertamax fuel in Yogyakarta. According to Rao and Sieben quoted in (Waluyo \& Pamungkas, 2003), Product Literacy or Product Knowledge is the scope of all accurate information stored in the consumer's memory, which is as good as his perception of product knowledge. Consumers with high knowledge will be realistic in choosing products according to expectations, where the higher knowledge of consumers in purchasing a product can increase consumers' ability to make more satisfying choices.

In this case, consumers can compare Pertamax fuel content with BBM of the Pertalite or Premium types. Of course, it has better quality. In terms of the octane value (Research Octane Number / RON), Pertamax has an octane value of 92, while Pertalite 90 and Premium have an octane value of 88 . It shows that the higher the octane content, the slower the fuel burns, so it does not leave residue on the engine, which later causes it to burn. This thing can interfere with performance. Then in terms of content, based on the official website of PT Pertamina. Pertamax fuel contains special additives that work as anti-rust protection against vehicle tank walls, fuel lines, and engine combustion chambers (Corrosion Inhibitor). It can clean the vehicle's inside (Detergency) and maintain the fuel's purity from the water mixture to complete combustion (Demulsifier). Pertalite has a green color with a clear appearance and contains no lead content and has a maximum sulfur content of 0.05 percent $\mathrm{m} / \mathrm{m}$ or equivalent to $500 \mathrm{ppm}$, which is better than the Premium type. Besides, the use of Pertalite results in more optimal engine combustion so that the engine is more powerful and smoother.

Moreover, the last one is Premium because it has the lowest octane among other types of fuel. Premium contains ingredients that use additional dyes that cause it to turn yellow and produce large amounts of NOx and Cox. In a vehicle engine, Premium's use in a high compression engine will cause the engine to experience a knocking.

Therefore, the higher the octane / RON, the better for the vehicle engine. The use of Pertamax on vehicles will suppress toxic gas because it does not contain lead. It is what makes it more environmentally friendly. The addition of additives in Pertamax will help maintain the engine so that it is not easily crusted, which will make the vehicle engine not easily damaged. Of course, it will save more maintenance costs on the vehicle.

In this study, the average respondent uses Pertamax fuel because they know Pertamax fuel's quality. Apart from not containing lead and being environmentally friendly, the Pertamax fuel has a higher RON than Premium and Pertalite fuels. It was quoted in the research conducted by (Weenas 2013) in (Sabilla, Mujiasih, \& Putra, 2014), which reveals that a fair assessment of product quality following the level of wants and needs will encourage consumers to purchase these products. It shows that the better the 


\author{
Khairunnisa \& Setiartitie \\ Willingness to Pay Analysis of First Fuel in Yogyakarta
}

consumer's knowledge or literacy of Pertamax BBM, the higher the willingness to pay consumers for Pertamax BBM in Yogyakarta.

This research is also in line with research conducted by (Lim, Kim, \& Yoo, 2017), his research shows that someone knowledgeable about a product is more likely to be willing to pay more for what is offered. The same result is found in research conducted by (Daud \& Aidar, 2017), which says that knowledge influences the willingness to pay.

\title{
The Effect of Income on Willingness to Pay.
}

Based on the results of the data that has been tested, the income variable has a significant and positive effect on consumers' willingness to pay for Pertamax fuel oil (BBM) in Yogyakarta. It happens because income is one of the factors that influence Pertamax BBM's purchase, which will also affect the availability of payments. For Pertamax fuel users, when their income changes, whether it increases or decreases, it will undoubtedly affect their Pertamax fuel purchases. Because it is influenced by consumer knowledge of Pertamax BBM (Product Knowledge), it was quoted in the research conducted by (Fauzan, 2018) for people who care about quality. They think that Pertamax is suitable for their vehicle, so even if the price increases, they will always use Pertamax.

Following the demand theory, when the community's income is high, its purchasing power increases. As a result, when the purchasing power is high, the ability to pay is also higher. Therefore, when the income goes up, it is followed by an increased demand for Pertamax fuel. High community income shows that the level of people's purchasing power is getting better. This research is also in line with research conducted by (Lestari \& Aliasuddin, 2016)in Lhokseumawe City. They concluded that income has a positive and significant effect on willingness to pay.

\section{The Influence of Vehicle Usage Frequency on Willingness to Pay}

Based on the research results, the variable frequency of vehicle use has a positive and significant effect on consumer willingness to pay for Pertamax fuel. This result is also following the initial hypothesis that vehicle use frequency has a significant effect on consumer willingness to pay for Pertamax fuel in Yogyakarta. Consumers using Pertamax BBM will be willing to pay a higher willingness to pay when the frequency of vehicle use increases. It is based on when consumers who almost use their vehicles every day will know more about the advantages of using Pertamax fuel in their vehicles. One of them is it is more economical even though the price is higher than others.

As with the survey conducted by Karimun Club Bangka Belitung, by buying Premium BBM, Pertalite, Pertamax with the same nominal money and usage with the same mileage and the result is Pertamax fuel is more efficient and profitable even though it is less literal (Basudewa, 2018). Therefore, when the frequency of use on a vehicle increases, the willingness to pay will also increase. 


\author{
Khairunnisa \& Setiartitie \\ Willingness to Pay Analysis of First Fuel in Yogyakarta
}

\title{
The Effect of Number of Vehicles Owned to Willingness to Pay
}

Based on the research that has been done, the variable the number of vehicles owned has a positive but insignificant effect on consumers' willingness to pay for Pertamax fuel. It relates to how respondents perceive a product used. Pertamax itself is a fuel with better quality compared to other types of fuel. Pertamax has a Research Octane Number (RON) at 92, Pertalite has RON 90, while Premium has RON 88. Where the higher the RON, the better the combustion. Therefore, the fuel with a high RON does not contain lead, which causes scaling of the vehicle engine. Besides, additives to Pertamax fuel will function as a cleaner for the fuel, which will later affect the durability of the vehicle engine. Yusworo Setyo Winoto, a motorcycle engineering teacher at SMKN 3 Bondowoso, said, "Vehicles with Pertamax consumption have longer service life because they are cleaner than others (Gatra, 2015).

Therefore, apart from when the community's income is high, it will also affect the level of Pertamax fuel consumption. And also because of the knowledge or literacy of consumers on product quality. Thus, regardless of the number of vehicles owned, it does not affect Pertamax fuel consumption. Because when consumers know the quality and advantages of BBM Pertamax, consumers will still fill their vehicles with Pertamax BBM. Furthermore, the average Pertamax BBM user respondents know their quality and have their perceptions of Pertamax BBM. Regardless of the number of vehicles owned, both cars and motorbikes, it does not affect willingness to pay because respondents will still use Pertamax BBM.

\section{Conclusion}

Based on the analysis that has been done, it can be concluded as follows: (1) The average value of willingness to pay (EWTP) in this study is IDR 10,545, with a consumer surplus of IDR 695.00. (2) Income variable has a significant effect on consumer willingness to pay for Pertamax BBM. It shows that the higher one's income, the more someone wants to pay for Pertamax fuel. (3) The frequency variable of vehicle use has a significant effect on consumer willingness to pay for Pertamax fuel. It happens because the more often someone uses a vehicle, the more someone wants to pay the willingness to pay because someone who uses his vehicle almost every day will feel the advantages of using Pertamax BBM. (4) The product literacy variable has a significant effect on consumers' willingness to pay for Pertamax fuel. It means that when consumers who use Pertamax BBM have an excellent knowledge of Pertamax BBM's advantages, they will increase their willingness to pay for Pertamax BBM. (5) The variable number of vehicles owned does not have a significant and positive effect on consumers' willingness to pay for Pertamax BBM. It shows that regardless of the number of vehicles owned, whether motorbikes or cars, consumers will still fill their vehicles using Pertamax fuel. It is motivated by the consumer's knowledge of Pertamax fuel, which has good motorized vehicles. Therefore, regardless of the number of vehicles owned, both cars and motorbikes, it does not affect willingness to pay because respondents will still use Pertamax BBM. 


\section{Khairunnisa \& Setiartitie \\ Willingness to Pay Analysis of First Fuel in Yogyakarta}

\section{References}

Basudewa, D. (2018). Quality fuel is the key to a healthy and powerful vehicle engine. Retrieved August 24, 2019, from Otospirit: https://www.otospirit.com/bbm-berk Quality-kunci-mesin-kendaraan-sehat-dan-bertenaga/52897

Daud, MY, \& Aidar, N. (2017). Willingness to Pay community of Banda Aceh city on availability of Solar Home System (SHS) in meeting household electricity needs. Jurnal Ilmiah Mahasiswa Ekonomi Pembangunan, 2(1), 216-226. https://doi.org/10.24815/jimekp.v2i1.2494

Fauzan, T. A. (2018). Determinant of pertamax fuel demand in Purwokerto. Eko-Regional Jurnal Pengembangan Ekonomi Wilayah, 13(2), 51-59. https:// doi.org/10.20884/1.erjpe.2018.13.2.1229

Gatra, S. (2015, December 07). Why is using pertamax more efficient? Retrieved August 24, 2019, from KOMPAS.com:

https://money.kompas.com/read/2014/12/07/094554126/Mengapa.Mengusers.Pert amax.Lmore. Hemat.?page $=$ all

Lestari, L., \& Aliasuddin. (2016). Willingness to pay masyarakat terhadap pembangunan jaringan gas bumi untuk rumah tangga di kota Lhokseumawe. Jurnal Ilmiah Mahasiswa Ekonomi Pembangunan, 1(2), 409-419. Retrieved from http://jim.unsyiah.ac.id/EKP/article/view/5834

Lim, S.-Y., Kim, H.-J., \& Yoo, S.-H. (2017). Public's willingness to pay a premium for bioethanol in Korea: A contingent valuation study. Energy Policy, 101, 20-27. https://doi.org/10.1016/j.enpol.2016.11.010

Rahman, W. (2015). Pengaruh kualitas produk pertamax terhadap keputusan pembelian konsumen. Retrieved from https://www.researchgate.net/publication/324783699 PENGARUH_KUALITAS PRODUK PERTAMAX TERHADAP KEPUTUSAN PEMBELIAN KONSUM

$$
\text { EN }
$$

Rankovic, N., Bourhis, G., Loos, M., \& Dauphin, R. (2015). Understanding octane number evolution for enabling alternative low RON refinery streams and octane boosters as transportation fuels. Fuel, 150, 41-47. https://doi.org/10.1016/i.fuel.2015.02.005

Sabilla, S., Mujiasih, E., \& Putra, N. (2015). Hubungan antara persepsi terhadap kualitas produk dengan intensi membeli pertamax pada karyawan PT. United Tractors TBK Jakarta. Jurnal Empati, 3(4), 570-580. Retrieved from https://ejournal3.undip.ac.id/index.php/empati/article/view/7618

Waluyo, P. \& Pamungkas, A. (2004). Analisis perilaku brand switching konsumen dalam pembelian produk handphone di Semarang. Jurnal Siasat Bisnis. 3(3), 1-29. 